\title{
DERLEME
}

\section{LOHUSA KÜLTÜREL ÖZELLIKLERI TANILAMA REHBERİ}

\author{
Gülbu TANRIVERDIं*
}

Alınış Tarihi: 08.12.2013

Kabul Tarihi: 29.12.2014

\section{ÖZET}

Türk halk kültürü'nde yeni doğum yapmış kadına “lohusa” denir. Çeşitli sosyo-kültürel yapılarda değişiklik gösteren lohusalık dönemi genellikle kırk gün olarak kabul edilir. Lohusalık dönemi, kadının ve bebeğin hastalıklara karşı savunmasız kaldı̆̆ ve korunması gereken bir dönem olarak algılanır. Bu dönem anne ve bebek için özel bir dönem olup her kültürde farklı uygulamaları kapsamaktadır. Bu uygulamaların bir kısmı zararlı uygulamalar olup, lohusanın să̆lı̆̆ını tehdit eder niteliktedir.

Bu araştırmada, literatür doğrultusunda lohusalık dönemine yönelik kültürel uygulamaları tanımlamada sağllk çalışanlarına yol gösterecek, 10 maddeden oluşan bir rehber oluşturulmuştur. Bu rehber geliştirilebilir, değiştirilebilir nitelikte olup ölçek değildir. Özellikle evde lohusa izlemi yapan hemşirelik ve ebelik lisans öğrencilerine yol göstermesi amacıyla hazırlanmıştır.

Anahtar Kelimeler; Lohusalık; kültürel özellikler; rehber; hemşire; hemşirelik.

\section{ABSTRACT}

\section{Guide for Identifying Cultural Features in Postpartum Woman}

In Turkish culture, a woman who has just given birth is referred to as being "lohusa". 40 days is generally time of confinement of a postpartum woman in various socio-cultural structures. It is perceived that the mother and the newborn remain vulnerable and must be protected against disease during the postpartum period. This time is considered a special period for both the mother and the newborn, each and every culture have different applications that the mother and newborn are subjected to. Some of these traditional practices are harmful and life threatening to the postpartum mother.

10 items were created in this study to guide healthcare workers in accordance with the literature of cultural practices during the period of confinement in this study. This guide can be improved, changeable, but it is not scale. The preparation in this study was specifically as a guide for nursing and midwifery undergraduate students for postpartum follow up in the home.

Keywords; Postpartum period; cultural features; guide; nurse; nursing.

\section{GİRIŞ̧}

Doğum sonrası dönem, anne ve bebek için özel bir dönem olup her kültürde farklı uygulamaları kapsamaktadır (Eğri ve Konak 2011). Türk halk kültürü'nde yeni doğum yapmış kadına "lohusa" denir. Çeşitli sosyo-kültürel yapılarda değişiklik gösteren lohusalık genellikle kırk gün olarak kabul edilir (Sein 2013). Bu dönem lohusa ve bebeğin hastalıklara karşı savunmasız kaldığ 1 ve korunması gereken bir dönem olarak algılanır. Türk kültüründe bu algılayış "lohusanın mezarı 40 gün açık olur" ifadesiyle vurgulanmaktadır (Eğri ve Konak 2011). Döneme yönelik yapılan kültürel uygulamalar lohusa ve bebeği her türlü hastalıklardan ve tehlikelerden korumak amaciyla uygulanan önlemler niteliğindedir (Sein 2013).
Lohusalık döneminde yeni anneye çevresi tarafından sosyal destek verilir, yardım edilir, ihtiyaçları karşılanır ve aktiviteleri sınırlandırılır. Guatemala'da halk ebesi hergün yada iki günde bir lohusayı ziyaret eder, bebeğin kordonunu kontrol eder ve anneye masaj yapar. Çinli kadınlara ise doğum sonu aynı ilgi 30 gün devam eder. Hindistan'da yeni anne ve bebek savunmasız olduğu için 40 gün kötü ruhlar ve hastalıklardan korunur. Batılı olmayan ülkelerde durum böyle iken batılı ülkelerde genel olarak doğum sonu uygulamalar biyomedikal modele temellenir (Kim Godwin 2003).

Doğum sonu kültürel uygulamaları tanımlayan 44 araştırmayı içeren sistematik incelemede yaygın uygulamaları organize edilmiş destek, dinlenme süreci, sınırlandırılmış aktiviteler, hijyen uygulamaları, diyet, yenidoğan

* Çanakkale Onsekiz Mart Üniversitesi Sağlık Yüksekokulu (Doç.Dr.) Hemşirelik Bölümü, e-posta: gulbu.tanriverdi@gmail.com 
bakımı, emzirme, doğum törenleri, yenidoğanın isimlendirilmesi ve sağlığı geliştirme gibi uygulamaları kapsadığı saptanmıştır (Grigoriadis, Dennis, Kenneth, Gail, Sarah, Lori et al. 2008). Bir başka çalışmada doğum sonu geleneksel uygulamalar beslenme, bakım-hijyen ve alkarısından korunma başlıkları altında ele alınmıştır (Geçkil, Şahin ve Ege 2009). Oranları değişmekle birlikte bütün kültürler benzer veya farklı olmak üzere doğum sonu kültürel uygulamalara başvurmaktadırlar. Mersin'de yapılan bir çalışmada kadınların \%87'sinin lohusalık döneminde kültürel uygulamalara maruz kaldığı saptanmıştır (Işık, Akçınar, ve Kadıoğlu 2010). Malezya'da doğum sonu dönemde kadınların annelerinin evinde kalması ve bakıma annenin yardım etmesi önceleri yaygın bir davranış iken artık bu uygulamanın değiştiği ve çoğu kadının kendi evinde kalmayı tercih ettiği belirlenmiştir. Malezyalı kadınlar arasında doğum sonu dönemde uygulanan altı geleneksel uygulama olduğu ve bu uygulamaların doğum sonu 40-48 günü kapsadığı belirtilmiştir. Bu uygulamalar aşağıda kısaca özetlenmiştir.

- Tuku: Top gibi saplı metal bir objedir. Sabah ateşte 1sitılır sonra beze sarılıp kadının karnının üzerinde yuvarlanır. Bu, masaj gibi bir uygulama olup sabah banyosundan önce ve sonra yapilır.

- Mengurut badan: Vücut masaj1 demektir. Haftada 3 kez yapılır. Baş ve boyundan kol ve bacaklara doğru yapılır. Masajda karına dikkat edilir. Yaklaşık 45-60 dakika sürer. Bu masajın kan dolaşımını iyileştirdiğine ve kas karamplarından koruduğuna inanılır.

- Barut: Barut kiyafetten yapılır. Normal doğum yapan kadının belinin etrafı sıkıca sarılır. $\mathrm{Bu}$ uygulamanın kadının vücudunun eski şekline dönmesine yardım ettiğine inanılır. Bu uygulama sabah vücut masajından sonra ve gece yapılır. Nadiren de öğlenleri yapılır.

- Salai: Çok yaygın olmayan bir uygulamadır. Salai ağaçtan yapılma bir aparat olup evin içine sabit olarak inşa edilir. Bu aparatın altında metal bir kabın içinde hafifce yanan odun yada kömür bulunur. Öğlen sonrası kadının bu aparat üzerine yatması teşvik edilmektedir. $\mathrm{Bu}$ uygulamanın lohusayı rahatlattığı ve sakinleştirdiği düşünülür.

- Air akar kayu: Tibbı bitkilerden yapılan tonik içecekler anlamına gelir. Malezya'da geleneksel tedavilerde kullanılan yaklaşık 100150 bitki vardır. $\mathrm{Bu}$ bitkilerin kan dolaşımını artırdığına ve sağlı̆̆ın bozulmasına engel olduğuna inanılır.
- Pantang makan dan minum: Bunun anlamı belirli yiyecek ve içeceklere yasak konulmasıdır. $\mathrm{Bu}$ dönemde kadının sadece etli yada balıklı pilav yemesine izin verilir. Lohusanın 1l1k su içmesi, soğuk içecekler ve kızartmalardan uzak kalması istenir. $\mathrm{Bu}$ beslenme biçiminin kan dolaşımını engelleyeceğine, bunun da kas ağrısına neden olacağına inanılmaktadır. Malezya'da yapılan bu geleneksel uygulamaların amacı kan dolaşımını artırmaktır. Çünkü kan dolaşımının iyi olması, sağlıklı olmanın gerekliliği olarak düşünülmektedir (Zamani 2001).

Doğum sonu uygulanan kültürel uygulamaların etkilerini Thi, Pasandarttorn and Rauyajin (2002) yarar, nötr, potansiyel zarar olmak üzere üç başlık altında ele almış ve kendi kültürleri içinde doğum sonu kültürel uygulamaları analiz etmişlerdir.

$\checkmark$ Yarar: Anne ve bebeğin daha fazla miktarda yemek yemesi, sıcak tutulmasi, dinlenmesi, ağır işlerden sakınılması, kimyasal gübre gibi zehirlerle temasa geçmemesi ve erken cinsel ilişkiye girmemesi yararlı kültürel uygulamalar olarak ifade edilmiştir.

$\checkmark$ Nötr: Saç taramama, aynaya bakmama, başka eve gitmeme, kulaklarına pamuk tıkama, uzun kollu gömlek giyme, çorap giyme, tırnak kesmeme gibi uygulamalar nötr uygulamalar arasında belirtilmiştir.

$\checkmark$ Potansiyel zarar: Yağlı yiyecek, meyve, balık, deniz ürünü, biftek gibi besin değeri yüksek olan gidalardan sakınma, su tüketimini sınırlama, kontraseptif yöntemi gereksiz bulma gibi davranışlar potansiyel zararlı davranışlar arasında bulunmuştur (Thi, Pasandarttorn and Rauyajin 2002).

Lohusanın sağlığını olumsuz etkileyen kültürel uygulamaların saptanmasinda ve yarar getirecek uygulamalarla değiştirilmesinde hemşire ve ebelere büyük sorumluluk düşmektedir. Hemşire ve ebelerin hizmet verdikleri lohusaların içinde yaşadıkları kültürde hangi tür uygulamalara maruz kalacağını önceden bilmeleri, buna yönelik veri toplamaları ve bu doğrultuda hizmeti planlamalarının, lohusanın sağlığının sürdürülmesi, erken tanı, komplikasyonların önlenmesi ve sağlığın geliştirilmesi açısından önemli olduğu düşünülmektedir.

$\mathrm{Bu}$ derlemede, lohusalık dönemine yönelik kültürel uygulamalar öncelikle literatür doğrultusunda incelenmiş ve bunun sonunda bir rehber hazırlanmıştır (Tablo 1). 
Tablo 1. Lohusa Kültürel Özellikleri Tanılama Rehberi

1.Hijyene yönelik kültürel uygulamalar
1.1.Banyo yapmama
1.2.Saç yıkamama
1.3.Diş firçalamama
1.4.Perineyi kolonya/sirke/tuzlu su vb şeylerle yıkama
1.5.Şampuan/Sabun kullanmama
1.6.Lohusanın çamaşırlarının ayrı yıkanması
1.7.Diğer

2.Lohusanın beslenmesine yönelik kültürel uygulamalar

2.1. Şekerli yiyeceklere ağırlık verme

2.2. Yağlı yeme

2.3. Sicak yeme/içme

2.4.Soğuk yememe/içmeme

2.5. Ac1/ekşi yiyeceklerden uzak kalma

2.6.Sebze ve meyveden uzak kalma

2.7. Sulu yemekler yeme

2.8. Fazla yeme

2.9. Diğer

3. Anne sütünün artırılmasına yönelik kültürel uygulamalar

3.1.Canının istediği her şeyi yiyebilme

4. Doğum sonu kanamayı durdurmaya yönelik kültürel

3.2.Fazla yeme

3.3. Şekerli daha fazla yiyecekleri tüketme

3.4. Lohusalık şerbeti içme

3.5. Memeye sicak masaj yapma

3.6.Höllük uygulaması

3.7.Diğer

uygulamalar

4.1. Zencefil içme

4.2. Muska yazdırma

4.3.Karına sicak uygulama yapma

4.4. Tatl1-cevizli besinler yeme

4.5.Kadını kekiğin buğusuna oturtma

4.6.Lohusa kadının yatağının üzerine "üzellik" (ya da“üzerlik") koyma

4.7.Diğer

5. Uterus involüsyonuna yönelik kültürel uygulamalar

6. Lohusanın yalnız birakılmaması ve lohusa ziyaretleri

5.1.Karının sıkıca sarılması

5.2.Karına masaj

6.1.Ziyarete kimseyi kabul etmeme

6.2.Ziyarete erkekleri kabul etmeme

5.3.Diğer

6.3.Ziyarete sadece yakın akrabaları kabul etme

6.4.Evde yalnız birakılmama

6.5.Ziyarete gelenlerin geleneksel yiyecekler getirmesi

6.6.Lohusa yalnız bırakılacaksa yanında bıçak vb. şeylerin birakilmas1

6.7. Diğer

\begin{tabular}{|c|c|}
\hline $\begin{array}{l}\text { Lohusayı albasmasından korunmaya yönelik kültürel } \\
\text { uygulamalar } \\
\text { 7.1.Muska takma } \\
\text { 7.2. Yatağa kırmızı bez bağlama } \\
\text { 7.3.Kırk gün dışarı çıkmama } \\
\text { 7.4.Yatağın yanına demir, bıçak, makas koymak } \\
\text { 7.4.Yastığının altına soğan } \\
\text { 7.6.Bebeğin yanına ayna, süpürge koymak } \\
\text { 7.7.Keçi kılından örülmüş ipi lohusanın yatağının çevresine } \\
\text { sarmak } \\
\text { 7.8.Eve çiğ et sokulmaması } \\
\text { 7.9.Düşük yapan kadının ziyaretine izin verilmemesi } \\
\text { 7.10.Lohusa kadınların birbirlerini ziyaret etmemeleri, ziyaret } \\
\text { etmeleri zorunlu ise kendilerinde bulunan çengelli iğnelerini } \\
\text { birbirlerine vermeleri } \\
\text { 7.11.Lohusanın odasında Kuran bulundurmak } \\
\text { 7.12.Lohusaya kırmızı bir tülbent bağlamak } \\
\text { 7.13.40 gün dışrıya çıkarmamak } \\
\text { 7.14.Lohusanın odasına su bırakmak } \\
\text { 7.15.Cenazeye gitmemek } \\
\text { 7.16. Adetli bir kadının, loğusa kadını ziyaret etmemesi } \\
\text { 7.17.Evde tek bırakılmaması } \\
\text { 7.18.Bebeğin kirli bezi yıkanınca, suyunun dışarı } \\
\text { dökülmemesi } \\
\text { 7.19.Loğusa kadının değirmene, fırına gitmemesi } \\
\text { 7.20.Lohusanın eşikten atlamaması } \\
\text { 7.21.Düğüne gitmeme } \\
\text { 7.22. Diğer }\end{array}$ & $\begin{array}{l}\text { 10. Diğer (masaj, dinlenme, sıcak tutma, tedavi yakl } \\
\text { vb.) } \\
\text { 10.1 Lohusalık süresince yatakta kalma } \\
\text { 10.2.Ev işi yapmama } \\
\text { 10.3.Lohusalık süresince yorucu işler yapmama } \\
\text { 10.4.Bedeni sıcak tutuma } \\
\text { 10.5.Meme başı çatlaklarına zeytinyağı sürme } \\
\text { 10.6.Diğer }\end{array}$ \\
\hline
\end{tabular}

$\mathrm{Bu}$ rehberin özellikle gebe izlemi yapan hemşirelik ve ebelik lisans öğrencilerine hangi kültürel yaklaşımlara yönelik veri toplanması gerektiği konusunda kolaylık sağlayacağı düşünülmektedir. Yanı sıra gebe izlemi yapan aile sağlığ elemanları, aile hekimleri ve ilgili diğer bütün sağlık çalışanlarına rehberlik edeceği düşünülmektedir. Rehberin araştırmalarda 
lohusalık dönemine yönelik kültürel özellikleri tanılamak amaciyla veri toplama aracı olarak kullanılması da önerilmektedir. Oluşturulan bu rehber ölçek olmayıp, geçerlilik ve güvenirliği yapılmamıştır. Geliştirilebilir, değiştirilebilir nitelikte olup amacına uygun olarak kullanıldığ 1 takdirde bakımın kalitesine olumlu yansıyacağ 1 düşünülmektedir.

\section{LOHUSALIĞA}

\section{KÜLTÜREL UYGULAMALAR}

YÖNELIKK

Lohusaya yönelik kültürel uygulamalar 10 başlık altında ele alındı.

\section{Hijyen Davranışları}

Lohusalık döneminde özellikle Asya ülkelerinde kadınların hijyen alışkanlıklarında sınırlamalara temellenen değişiklikler belirtilmektedir. $\mathrm{Bu}$ değişikliklerin ise genel olarak banyo yapmama, saç yıkamama, saç taramama, diş firçalamama, soğuk sudan uzak kalma şeklinde olduğu görülmektedir. Çin geleneklerinde "Zuo yuzei", Doing the month"olarak adlandırılan bu dönemde yeni anne, saçlarını yıkamamalı, soğuk suya dokunmamalıdır. Soğuk ya da rüzgar annenin eklemlerinde ağrı yapabilir düşüncesi hakim olan Çin'de lohusanın evinin camı ve kliması kapalı olmalıdır (Kim-Godwin 2003). Fuji'de de "Zuo yuzei” önemli bir kültürel uygulama olup banyo ya da saç yıkamama ve diş firçalamama gibi sınırlamaları kapsamaktadır (Raven, Chen, Tolhurst and Garner 2007). Meksikalı Amerikan kadınlarda doğum sonrası lohusanın 40 gün banyo yapmasina izin verilmez (Kim-Godwin 2003). Taylandlı kadınlarda yapilan bir çalışmada, 1-90 gün arasında değişen sürelerle kadınların \%61'inin duş almadığı, şampuan kullanmadığı saptanmıştır (Kaewsarn, Moyle, and Creedy 2003a). Benzer uygulamaların Taylandlı hemşireler arasında da kabul gördüğü saptanmıştır (Kaewsarn, Moyle, and Creedy 2003b). Kuzey Vietnam'da yapılan araştırmada 7-30 gün arasında duş almama/şampuan kullanmama yaygin geleneksel uygulamalar arasındadır. $\mathrm{Bu}$ kültürde saçı taramanın da gelecekte baş ağrisına neden olacağ düşünülmektedir. Ayrıca erken dönemde banyo yaparlarsa ve şampuan kullanılırsa bunun doğum sonu dönemdeki kadına rüzgarın gireceği ve bunun da hastalıklara neden olacağ 1 düşünülmektedir. Kadınların bu dönemde başkalarına kötü şans getireceklerine inanılır, onların çamaşırları evin diğer üyelerinden ayrı y1kanır (Thi, Pasandarttorn and Rauyajin 2002). Özsoy ve Katabi'nin (2008) çalışmasında doğum sonu perine hijyenini Türk kadınlarının \%46.6'sının kolonya ve sirkeyle; İranlı kadınların ise \%45.3'ünün tuzlu, sirkeli ve alkollü suyla yaptıkları saptanmıştır.

\section{Değerlendirme}

- Yararlı uygulamalar: Lohusanın 1Sısının korunması, çamaşırlarının enfeksiyon açısından ayrı yıkanması, klima karşısında bırakılmaması yararlı uygulamalar olarak değerlendirilebilir.

- Potansiyel zararlı uygulamalar: Kadının lohusalık süresince ya da belli bir süre duş almaması, diş firçalamaması, saç taramaması, perine hijyeninde su dışında kullanılan maddeler potansiyel zararlı uygulamalar olarak değerlendirilebilir.

\section{Beslenme}

Doğum sonu kültürel uygulamaları oluşturan en önemli öğelerden birisi de lohusa kadının beslenmesidir. Hemen her toplumda lohusa kadına bu döneme özel diyet uygulanır. Diyetteki en önemli amaç kadının eski haline daha kısa sürede dönmesi ve sütünün olmasını sağlamaktır. Türk kültüründe bu diyet, bol kalorili, proteinli ve suludur (Eğri ve Konak 2011). Taylandlı kadınlar arasında doğum sonu yaygın uygulamalardan biri sıcak içecekler tüketmektir (Kaewsarn, Moyle, and Creedy 2003a). Taili hemşirelerin \%49'unun da doğum sonu dönemde sıcak içeçekler içilmesi konusunda hemfikir oldukları belirlenmiştir (Kaewsarn, Moyle, and Creedy 2003b). Çinli kadınlarla yapılan bir araştırmanın sonuçlarına göre kadınların \%90'1 "doing th month" süresinde soğuk, sert ve ekşi yiyecek yememektedir (Wang, Wang, Zanzhou, Wang and Wang 2008). İran'da doğum sonu dönemde lohusa kadına Türk kültüründe olduğu gibi bol kalorili ve yağl1 besinler verilmektedir. Hint, Çin, Tayland ve Guatemala kültürlerinde diyet temel olarak "ying-yang" dengesini sürdürmeye yöneliktir. "Ying-yang" teorisi zit güçlerin dengesi üzerine kuruludur. Gebelik sicak bir dönem olarak kabul edilerek gebe kadından soğuk besinler yemesi istenirken, doğum sonu dönemde kadın doğumla birlikte sıcaklık kaybettiği için bu dönemde ise sıcak besinler alması istenmektedir. Besinlerin sicak veya soğuk olarak kabul edilişleri kültürler arasında farklılıklar gösterebilir. Besin bir kültürde sıcak iken, başka bir kültürde soğuk olarak kabul edilebilir. Örneğin, Hint Kültüründen et, yumurta, balık, tereyağ 1 sicak besinler olarak kabul edilirken buğday, koyu yeşil yapraklı sebzeler ise soğuk besinler olarak kabul edilmektedir. Lohusalık döneminde, soğuk besinlerin alınmasının kadın ve bebek için 
hastalığa neden olacağı inanc1 vardır. $\mathrm{Bu}$ sebepten dolayı loğusa kadına sicak olarak kabul edilen besinler verilmektedir (Eğri ve Konak 2011).

\section{Değerlendirme}

Yararlı uygulamalar: Lohusanın beslenmesine ayr1 bir özen gösterilmesi, beslenme konusunda destek verilmesi yararlı uygulamalar olarak değerlendirilebilir.

- Potansiyel zararlı uygulamalar: Doğum sonu beslenmenin içeriğini şekerli ve yağlı besinlerin oluşturması, yeşil yapraklı sebzelerden uzak tutulması ve lohusayı aşırı beslemeye yönelik kültürel uygulamalar potansiyel zararl1 uygulamalar olarak değerlendirilebilir.

\section{Anne Sütünün Artırılması}

Doğum sonu hemen her toplumda lohusa kadına bu döneme özel diyet uygulanmasındaki en önemli amaçlardan biri kadının sütünün olmasını sağlamaktır (Eğri ve Konak 2011). Mersin'de lohusanın sütünün çekilmemesi ve bol olması için istediği her şeyi yemesi gerektiğine inanılır yoksa lohusanın sütü çekilir, gögüsleri şişer, "umma" olur inanc1 yaygindır. Umma olan kadının korkutularak sütünün geri geleceğine inanılır. (Çıblak Coşkun 2011). Erzurum'da yapılan kalitatif bir araştırmada kadınların, lohusaya sütünün bol olması ve çabuk yatağından kalkması için yumurta kayganası, herle çorbası, hasıta, bulgur pilavı yedirdikleri saptanmıştır (Bolçay 2011). Şanlıurfa'da annenin sütünün gelmesi için boynuna süt taş1 asıldığı belirlenmiştir (Başal 2006). Adıyaman'da kadınların \%82.8'inin bulamaç adını verdikleri tatlıyı, \% 69.6'sının ise pekmez ve tereyağ karışımını içtiği saptanmıştır (Geçkil, Şahin ve Ege 2009). Mersin'de yapılan bir araştırmada sütü artırmaya yönelik uygulamalar arasında; lohusa şerbeti içme (\%55.3), fasulye, nohut, üzüm ve süt gibi içecekleri tüketmeme (\%19.1), höllük uygulaması (\%12.7) yer almıştır (Işık, Akçınar ve Kadıŏlu 2010). Çanakkale Romanlarında yapılan kalitatif araştırmada lohusa kadının sütü olması için memelerine sıcak su konduğu ve dalak yedirildiği saptanmıştır (Tanrıverdi, Ünüvar, Yalçın, Sürer, Acar, Akçay ve ark. 2012). Gaziantep'te yapilan bir araştırmada kadınların doğum sonu dönemde anne sütünü artırmaya yönelik pekmez/helva yemek (\%68.7), bulgur pilavı yemek (\%61.3) ve şerbet içmek (\%46.0) gibi uygulamaları saptanmıştır (Lafçı ve Erdem 2014). Kütahya'da annelerin en yaygın olarak sütlerini artırmak için çok su (\%62) ve süt (\%24.1), tatlı (\%20.8), incir $(\% 18.1)$, soğan (\%17.6), meyve-meyve suyu
(\%16.2), rezene çayı (\%14.8) ve sebzeyeşillik (\%13.9) tüketilmesi gerektiğine inandıklarını saptanmıştır (Gökduman ve Akdolun Balkaya 2013). Sütlü ve arkadaşları (2013) Ödemiş’te yaptıkları çalışmada annelerin sütü artırmaya yönelik \%30.7'sinin sulu, \% 24'ünün soğan, \%14'ünün helva yediklerini saptamışlardır. Şanlıurfa'da yapılan çalışmada annelerin \%43'ü sütü bol olsun diye sik sik emzirdiğini, \%27.5'u sıvı gidalar aldığını ve \%17'si ise pilav yediğini ifade etmiştir (Dinç 2005).

\section{Değerlendirme}

- Yararlı uygulamalar: Yeterli sivi almak ve yeterince dinlenmek, annedeki süt miktarını arttıran en önemli faktörlerdendir. Yukarıda sayılan uygulamalar arasında sıvı tüketiminin artırılması, yeşil sebzeler, bulgur pilavı ve dut hoşafi tüketilmesi ve sık sık emzirilmesi yararlı uygulamalar olarak değerlendirilebilir.

- Potansiyel zararlı uygulamalar: Anne sütünün artırılmasına yönelik hemen hemen bütün kültürlerde kaloriden zengin ve dengeli olmayan bir beslenme tercih edildiği görülmektedir. Bu durum obesite başta olmak üzere sağlık açısından bir risk olarak değerlendirilebilir. Meme üzerine konan sicak toprak (höllük) ise enfeksiyon kaynağı olarak değerlendirilebilir.

\section{Doğum Sonu Kanamayı Durdurma}

Kuzey Vietnam'da yapılan bir araştırmada lohusa kadının bu dönemde karnına yapılan sıcak uygulama ile kirli kanın daha kısa sürede vücuttan ayrılacağı inanışı saptanmıştır (Thi, Pasandarttorn and Rauyajin 2002; Thi 2004). Çin ve Tayland kültüründe zencefil sıcak bir besin olarak kabul edilmekte ve zencefilin doğum sonu dönemde rahimde bulunan plasenta parçalarını atarak kanamayı durdurduğuna inanılmaktadır. İran kültüründe, doğum sonu dönemde kanamayı durdurmak için muska yazdırmak, karına sicak uygulama yapmak, tatl1cevizli besinler yemek, kadını kekiğin buğusuna oturtmak, lohusa kadının yatağının üzerine "üzellik" (ya da“üzerlik") koymak gibi uygulamaların yer aldığı ifade edilmektedir (Eğri ve Konak 2011). Gaziantep'te yapılan bir araştırmada lohusa kadınların kanamayı durdurmaya yönelik en sik yaptıkları uygulamalar arasında ayaklarının altına kiremit 1sıtıp koymak, karnına soğuk su dökmek, höllük 1sitıp koymak, kiremit 1sitıp altına koymak, karnına bastırmak, ayaklarını yükseltmek, kasıklara sirkeli bez koymak, hocaya okutmak ve bele yak1 koymak gibi uygulamalar yer aldığ 
saptanmıştır (Lafçı ve Erdem 2014). Nevşehir kırsalında yapılan araştırmada doğum sonu kanamayı durdurmaya yönelik uygulamalar arasında kadınların \%46.2'sinin kanama dursun diye beklediği, \%14.7'sinin ise toprağa oturduğu saptanmıştır (Çakırer ve Işı1k Çalışkan 2010).

\section{Değerlendirme}

- Yararlı uygulamalar: Doğum sonu kanamayı durdurmaya yönelik uygulamaların hiçbiri yararlı bir uygulama olarak değerlendirilememektedir.

- Potansiyel zararlı uygulamalar: Doğum sonu dönemde kadınların kanamayı durdurmak için sicak uygulamalara odaklandikları ve bu uygulamaların ise kanamayı durdurmamakla birlikte kanamanın daha çok artmasına neden olabileceği için zararlı uygulamalar olarak değerlendirilmektedir. Ayrıca kanamanın durmasinı beklemek olabilecek komplikasyonların önlenememesi açısından önemli bir risk oluşturduğu düşünülmektedir.

\section{Uterus involüsyonu}

Ürdünlü kadınlarda yapılan bir araştırmada kadınların \%35'ine göre doğum sonrası karının sıkıca sarılmasının doğru bir davranış olduğu saptanmıştır (Jarrah and Bond 2007). Özsoy ve Katabi'nin (2008) çalışmasında Türk kadınlarının \%92'sinin, İranlı kadınların ise \%99.3'ünün uterus involüsyonunu sağlamak amacıyla karını sardıkları saptanmıştır. Yanı sıra kadınların Adıyaman'da yapılan araştırmada \%64.5'inin (Geçkil, Şahin ve Ege 2009), Tokat'ta yapılan araştırmada \%64.8'inin (Gölbaşı ve Eğri 2010) ve diğer bir araştırmada \%52,9'unun (Tosun Güleroğlu, Başer, Cerit ve Yüzer 2014) doğum sonrası karınlarını sardıkları saptanmıştır. Mersin'de yapılan bir araştırmada karın sarkmasını engellemek için karının sarılmasının yanı sıra pirinç çorbası içirilmesi ve et yedirilmesinin koruyucu olduğu düşünülmektedir (Iş1k 2010).

\section{Değerlendirme}

- Yararli uygulamalar: Beslenmenin ana besin öğelerini içermesi (et, karbonhidrat) lohusalık sürecinde olumlu bir davranış olarak değerlendirilebilir.

- Potansiyel zararlı uygulamalar: Uterus involüsyonu için genel olarak yapılan uygulamanın karını sarmak olduğu görülmektedir. Bu uygulama dolaşımı engelleyip istenmedik sonuçlara yol açabileceği için zararlı olarak değerlendirilebilir.

\section{Albasmasindan Korunma}

Türk Halk Kültürü'nde, kişi uykudayken üzerine "cin" olduğu düşünülen bir ağırlığın çökmesine "al basması" denir. Özellikle doğum yapmış, loğusa kadınların ilk günlerde maruz kalacağı bir sıkıntı hali, ateşli bir hastalık olarak yorumlanır. Halk inanışına göre "al karısı" denen yaşlı bir cin, gece yalnız yatan lohusaya musallat olur. Al basan kişi birtakım şeyler görüp sesler duyduğunu söyler (Demirel Bozkurt, Hadımlı ve Sevil 2014).Tüm Türk boylarında albasmasından korunmak için benzer uygulamalar yapılmaktadır (Karaaslan 2011). Albasmasindan korunmada kültürel olarak alınan tedbirler genel olarak; muska yazdırma, yatağa kırmızı bez bağlamak, kırk gün dışarı çıkmamak, yatağın yanına demir, bıçak, makas koymak, yastığının altına soğan koymak, bebeğin yanına ayna, süpürge koymak, keçi kılından örülmüş ipi lohusanın yatağının çevresine sarmak, eve çiğ et sokulmaması, düşük yapan kadının ziyaretine izin verilmemesi, lohusa kadınların birbirlerini ziyaret etmemeleri, ziyaret etmeleri zorunlu ise kendilerinde bulunan çengelli iğnelerini birbirlerine vermeleri, lohusanın odasinda Kuran bulundurmak, lohusaya kırmızı bir tülbent bağlamak, kadının odasına su birakmak, cenazeye gitmemek, adetli bir kadının loğusa kadını ziyaret etmesine izin vermemek ve evde tek birakılmamak gibi uygulamalar yapılmaktadır (Artun 1998; Eğri ve Konak 2011; Kaaaslan 2011; Lafc1 ve Erdem 2014). İranlı kadınların da benzer şekilde Kuran'ı lohusanın başının üzerine konması, iki lohusa kadının aynı odada bulunmaması, kadının kırk gün dışarıya çıkarılmaması gibi uygulamalar yaptıkları bilinmektedir. Hint kültüründe de lohusa kadının yatağının kenarına ateş, su, orak konulmas1 gibi benzer uygulamalar söz konusudur (Eğri ve Konak 2011).

Yapılan bir araştırmada albasmasını önlemek için kadınların \% 72,5'inin yattığı odaya Kuran-1 Kerim astığı, \%63,7'sinin odadaki 1şı̆ 1 asla kapatmadığ $1, \% 70,6$ 'sının odaya âdet (menstrüasyon) gören kadının girmesine izin vermediği ve $\% 52$ 'sinin odasında erkek elbisesi bulundurduğu belirlenmiştir (Tosun Güleroğlu ve ark. 2014). Adana yöresinde yapılan araştırmada albasmasından korunmak için yeni evlilerin ve adetli kadınların lohusa ziyaretine gelmediği, bebeğin ilk kakalı bezi, çocuk yara dökmesin diye kırk gün odanın eşiğinin altına konduğu saptanmıştır (Başçetinçelik 2009). 
Bakır ve arkadaşları (2011) yaptıkları çalışmada kadınların \% 46.8'inin albasmasına inandığını ifade ettiklerini saptamışlardır. Araştırmaya katılan kadınların \%46.8'i alkarısının neye benzediğini tanımlayamadıkları, albasmasından korunmak için \%41.5'inin kırmız1 örtü kullandığ1, \% 25.5'inin ise yanlarında bir metal parça bulundurma gibi önlemler aldığı saptanmıştır (Bakır, İnci, Alan, Gökyıldız ve Elmas 2011). Albasmasından korunmak için Karaman'da bebeğin kirli bezi yıkanınca suyunun dışarı dökülmediği (\%31.7), lohusa kadının değirmene, firına gitmediği, eşikten atlamadığı, düğüne gitmediği, eve yabancı kabul edilmediği (\%50.7), kırklı çocuk ve kadının yalnız bırakılmadığ 1 , kırk gün dışarı çıkarılmadığı (\%64.1) belirlenmiştir (Yalçın 2012). Mersin'de yapılan bir araştırmada elde edilen bulgulara göre kadınların lohusalık döneminde yaptığı uygulamaların \%74.4'ünün albasması inanışıyla bağlantılı olduğu belirlenmiştir. Bu uygulamalar \%51.4'ü 40 gün evden çıkmama, \%34.2'si bir diğer lohusayla bir araya gelmeme, \%28.5'i adet görmekte olan ziyaretçiyi kabul etmeme, \%20'si muska bulundurma, \%17.1'i yastık altına makas ve bıçak koyma, \%11.4'ü yatağın yakınına soğan ve sarımsak asma, $\% 8.5^{\prime}$ i yastı̆̆ın yanında iğne veya şiş bulundurma, \%5.7'si vücudu kesip kan akıtma, \% 2.8'i türbeden getirilen bezi eve asma şeklindedir (Işık, Akçınar ve Kadıoğlu 2010). Çanakkale Romanlarında yapılan kalitatif araştırmada lohusa kadın yalnız kalacaksa yanına bıçak ve al yazma konulduğu ifade edilmiştir (Tanrıverdi, Ünüvar, Yalçın, Sürer, Acar, Akçay ve ark. 2012). Gaziantep'te albasmasinı önlemeye yönelik en sik yapılan uygulamalar arasında yattığı odaya ekmek, makas, süpürge, Kur'an-1 Kerim vb. Koymak (\%48.0), lohusa kadının yastı̆̆ının altına iğne koymak (\%48.0), albasmasının geçmesi için ise en yaygın hocaya okutma ve kurşun döktürme yer almıştır (Lafçı ve Erdem 2014).

\section{Değerlendirilme}

- Yararl uygulamalar: Gebeye sosyal destek sağlamak adına yalnız bırakmamak istendik bir uygulama olarak değerlendirilebilir.

- Potansiyel zararlı uygulamalar: Lohusanın dışarı çıkamaması, yatağında ve odasında lohusaya zarar verebilecek iğne, bıçak gibi şeylerin konması, odada bekletilen bebeğin kirli bezinin enfeksiyon ve hijyen açısından rahatsız edici olması gibi uygulamalar istenmedik oldukları söylenebilir. Yanı sıra albasması olarak nitelendirilen geleneksel yöntemlerle baş edilmeye çalışılan bu durumun doğum sonu enfeksiyonu ve depresyonu gibi sağlık sorunlarının erken tanısını geciktirecek olumsuz bir durum olarak ta değerlendirilmektedir

\section{Lohusanın Yalnız Bırakılmaması ve} Lohusa Ziyaretleri

Doğum sonu ziyaretleri bu dönemin önemli kültürel özelliklerindendir. Çin kültüründe bu dönemde lohusa kadının yanına sadece yakın akrabaları gelir, arkadaşları ve diğer uzak akrabalar bu kırk günlük süre bittikten sonra anne ve bebeği ziyaret ederler (Eğri ve Konak 2012). Bebek doğduktan sonra lohusa kadına, süt, sütlü yiyecekler, çorba götürülür. Lohusa ziyaretine gelenlere kırmızı renkli lohusa şerbeti ikram edilir (Artun 1998 Erzurum'da çocukları yaşamayan kadın lohusayı ziyarete gelmez inanışı hakimdir (Bolçay 2011). Çanakkale Romanlarında yapılan araştırmada lohusa kadının yalnız bırakılmadığı ifade edilmiştir (Tanrıverdi, Ünüvar, Yalçın, Sürer, Acar, Akçay, Hacıalioğlu ve ark. 2012). Tokatta yapılan araştırmada kadınların \%80.3'ünün (Gölbaşı ve Eğri 2010); Adıyaman'da yapılan araştırmada \%62.6'sının evde yalnız bırakılmadığı saptanmıştır (Geçkil, Şahin ve Ege 2009). Tekirdağ'da lohusanın 40 gün dışarı çıkarılmadığı ve yalnız bırakılmadığı saptanmıştır (Artun 1998). Tosun Güleroğlu, Başer, Cerit ve Yüzer (2014) çalışmalarında kadınların \%81,4'ünün bu dönemde evde tek başına bırakılmadığı saptanmıştır.

\section{Değerlendirilme}

- Yararlı uygulamalar: Doğum sonu dönemde lohusa kadının yanına fazla ziyaretçi gelmemesi hem lohusa kadının kendisinin dinlenmesi hem de bebeğiyle ilgilenmesi için yeterince zaman ayırabilmesi açısından yararlı olduğu düşünülmektedir. Fazla ziyaretçinin gelmemesi enfeksiyon kontrolü açısından, lohusanın aile bireylerince yalnız birakılmaması ise sosyal destek açısından yararlı olarak değerlendirilebilir.

- Potansiyel zararlı uygulamalar: Lohusa ve bebeğe yapılan yoğun ziyaretler lohusanın dinlenememesi, bebek ve kendisi için enfeksiyon riski olarak düşünülebilir. Yanı sıra lohusanın 40 gün dışarı çıkmaması lohusanın ve bebeğin sağlık kontrolleri açısından engel oluşturabilir, sosyal yaşamı engelleyebilir, doğum sonu depresyon riskini artırabilir, loğusa üzerinde baskı oluşturabilir değerlendirilebilir.

\section{Lohusanın Kırklanması}

Bütün Türk topluluklarında lohusalık döneminde hem annenin hem de çocuğun çeşitli 
tehlikelere maruz kalabileğine inanılmaktadır. $\mathrm{Bu}$ süreçte loğusa ve bebek için birtakım kültürel tedbirler alınmakta ve bu sürecin bitiminde "kırklama" adı verilen bir tören ile bu tehlikenin atlatıldığına inanılan yapılmaktır (Demirel, Hadımlı ve Sevil 2014). Doğumdan sonraki kırk günün sonunda, artık anne ve çocuğun tehlikelere karşı etkilenme güçleri azalmıştır. Toplumun her kesiminde, benzer veya değişik şekillerde anne ve çocuk kırklanır. Ancak, kırkınc1 güne gelmeden yapılan törenler de vardır. Kimi bölgelerimizde üçleme, yedileme adlarıyla doğumdan sonraki 3 . ve 7 . günde ve yarı kırk adıyla 20. günde törenler yapılmaktadır (Başçetinçelik 2009). Erzurum'da kırklama uygulamasının 40 tane olmak koşuluyla findık, arpa, boncuk, taşın dualarla okunup yıkama suyuna atılması ve bu suyla lohusa ve bebeğin evde ya da hamama götürülüp y1kanması şeklinde yapıldığı saptanmıştır (Bolçay 2011). Erzurum'da yapılan bir başka çalışmada doğum sonu kadınların \% 35.1'inin kırklama yaptığını ve \%15.3'ünün ise bu süreçte dişarı çıkmadıklarını saptamışlardır (Çelik ve ark. 2012). Çin, İran ve Hindistan toplumlarında bebek ve anne kırk gün dışarıya çıkarılmaz. 40. günde Türk toplumundaki gibi kırk çıkarma yapılır (Eğri ve Konak 2012). Tokatta yapılan bir araştırmada lohusa kadınların \%91.5'ine kırk çıkarma \%81.8'ine yirmi kırkını çıkarma uygulaması yapıldığı belirlenmiştir (Gölbaşı ve Eğri 2010).

Çanakkale Romanlarında yapılan kalitatif araştırmada lohusanın kırkıncı gün hamama götürüldüğü, karabiber, kırmızı biber, kimyon gibi suda kaynatılan baharatlarla yıkandığı, normal doğum esnasında kemikleri birbirinden ayrıldığ 1 için lohusanın çarşafa sarılıp ellerinden, ayaklarından, belinden çekildiği ve böylece kemiklerin yerine getirildiği gibi uygulamalar yapıldığı saptanmıştır (Tanrıverdi, Ünüvar, Yalçın, Sürer, Acar, Akçay, Hacıalioğlu ve ark. 2012).

\section{Değerlendirme}

- Yararlı uygulamalar: Kırklama kültürel olarak kabul gören bir uygulama olarak değerlendirildiğinde bu uygulamanın yapılmasının lohusa kadınlarda manevi rahatlama sağlayacağı düşünülebilir.

- Potansiyel zararlı uygulamalar: Kirklama işleminin hamamda yapılması, suyun içine baharat vb. şeylerin konması, kadının çarşafa sarılarak çekilmesi istenmedik uygulamalar olarak değerlendirilebilir.

\section{Cinsel İlişkiden Sakınma}

Lohusalık döneminde 40 gün kadın aralıklı olsa da kanaması olduğu için kirli sayılır. $\mathrm{Bu}$ süre bitene kadar cinsel ilişkiye girmesine izin verilmez (Eğri ve Konak 2011, Yalçın 2012). Gölbaş1 ve Eğri'nin (2010) Tokat'ta yaptıkları araştırmada kadınların \% 90.8'inin, Lafçı ve Erdem (2014) Gaziantep'te yaptıkları araştırmada \%82.7'sinin lohusalık döneminde cinsel ilişkiye girmediği saptanmıştır. Zambiyalı kadınlar ise doğumdan sonraki 3-7 ay boyunca cinsel ilişkiye girmezler, cinsel ilişkiye girilirse kadında doğum humması olacağ 1 , ilişki sonrası bu hastalığın erkeğe geçeğine inanılmaktadır (Eğri ve Konak 2011). Adıyaman'da yapılan araştırmada kadınların \%57.9'unun 40 gün boyunca cinsel ilişkiye girmediklerini ifade ettikleri saptanmıştır (Geçkil, Şahin ve Ege 2009). Tosun Güleroğlu ve arkadaşlarının (2014) çalışmasında kadınların \%89,2'sinin doğumdan sonraki 40 gün içerisinde cinsel ilişkiye girmediği saptanmıştır. Taylandlı kadınlarla kadın sağlığ 1 ve uterusun küçülmesine engel olabileceği düşüncesiyle ortalama 63 gün olmak üzere 7-450 gün arasında cinsel ilişkiden sakınanların olduğu saptanmıştır (Kaewsarn, Moyle, ve Creedy 2003a). Taylandlı kadınlarla yapılan bir diğer çalışmada yine zararlı olduğu ve uterusun sarkmasına neden olacağ 1 için erken cinsel ilişkiye girmedikleri saptanmıştır (Thi, Pasandarttorn ve Rauyajin 2002, Thi 2004). Çin geleneklerinde (Kim-Godwin 2003) ve Fuji'de de lohusalık dönemi, cinsel ilişkiden sakınma gibi sınırlamaları kapsamaktadır (Raven, Chen, Tolhurst and Garner 2007). Taili hemşirelerle yapılan çalışmada hemşirelerin \%78.8'i lohusalıkta 8-10 hafta boyunca cinsel ilişkiden kaçınılması konusunda hem fikir oldukları saptanmıştır (Kaewsarn, Moyle, ve Creedy 2003b).

\section{Değerlendirme}

- Yararlı uygulamalar: Lohusalık döneminde erken cinsel ilişkiden kaçınmak sağlık açısından enfeksiyonların önlenmesi, epizyotomilerin iyileşmesi ve olası ağrılı cinsel ilişkinin önlenmesi açısından yararlı bir uygulama olarak değerlendirilmektedir.

- Potansiyel zararlı uygulamalar: Cinsel ilişkinin uterusun sarkmasına neden olacağı gibi yanlış bilgilerle sağlı açısından risk oluşturmamasına rağmen çok uzun süre cinsel ilişkiye girmemek (40 günden 450 güne ulaşan farklı kültürel uygulamalar mevcut) eşler açısından istenmedik sonuçlar doğurabileceği düşünülmektedir. 
10. Diğer (masaj, dinlenme, sıcak tutma, tedavi yaklaşımları vb.)

Guatemala'da halk ebesi hergün yada iki günde bir lohusayı ziyaret eder, bebeğin kordonunu kontrol eder ve anneye masaj yapar (Kim Godwin 2003). Çin geleneklerinde "Zuo yuzei", Doing the month"olarak adlandirılan bu dönemde yeni anne, güneş 1şı̆̆ına çıkmamalı, yürümemeli, ağlamamalıdır (Kim Godwin 2003). Fuji'de de lohusalık ev işi yapmama ve yatakta dinlenme gibi sinırlamaları kapsamaktadır (Raven, Chen, Tolhurst ve Garner 2007). Lohusalar dışarı çıkmazlar, dini uygulamalara katılmazlar, başkalarına kötü şans getireceklerine inanılır. $\mathrm{Bu}$ dönemde kadının dinlenmesi önemlidir (Thi, Pasandarttorn and Thi 2002). Türk kültünde ise doğum sonrası kültürel uygulamalar arasında bele yakı koyma, karına bastırma, karına soğuk su dökme, hocaya okutmak, bele sicak uygulama yapmak gibi uygulamalar bulunmaktadır (Eğri ve Konak 2011). Karaman'da yapılan bir araştırmada kadınların \%41.5'inin üşümesin diye doğumdan önce özel olarak hazırlanmış elenmiş, torbalara konmuş toprağa yatırıldığı saptanmıştır (Yalçın 2012).

\section{KAYNAKLAR}

Artun E. Tekirdağ Halk Kültüründe Geçiş Dönemleri Doğum-Evlenme-Ölüm. Bir Türk Dünyası İncelemeleri Dergisi 1998;9-10:85-107.

Bakır E, İnci H, Alan S, Gökyıldız Ş, Elmas E. Adana'da Albasması Inanışı ve Geleneksel Uygulamalar. Lokman Hekim Journal 2011;1(1):138.

Başal HA. Türkiye'de Doğum Öncesi, Doğum ve Doğum Sonrası Çocuk Gelişimi ve Eğitimine İlişkin Gelenek, Görenek ve İnançlar. Eğitim Fakültesi Dergisi 2006; XIX (1): 45-70.

Baştançelik A. Adana Halk Kültüründe DoğumEvlenme-Ölüm. Adana. Ulusoy Ofset, Altın Koza Yayınları. 2009, p:50

Bolçay E. Erzurum'da Doğum Öncesi, Doğum Sonrası ve Çocukluk Dönemiyle Alakalı Gelenekler. Kastamonu Eğitim Dergisi 2011;19(2): 587-600.

Çakırer N, Işık Çalışkan Z. Nevşehir İli Ağılı Köyünde Gebelik, Doğum ve Lohusalığa Yönelik Geleneksel Uygulamalar. TAF Prev Med Bull 2010; 9(4):343-48.

Çıblak Coşkun N. Mersin'de Doğumla İlgili Ẩdetlerin Halk Hekimliği Yönünden İncelenmesi. Lokman Hekim Journal of Medical History and Folk Medicine 2011; 3(1): 1-12.

Demirel Ö, Hadımlı, Sevil Ü. Günümüzde lohusalıkta devam edan albasması ve kırklama uygulamaları. Ege Üniversitesi Hemşirelik Fakültesi Dergisi 2014;30(1):111-126.

\section{Değerlendirme \\ - Yararli uygulamalar: Yukarıdaki} uygulamaların çoğunluğu doğum sonu kadına sosyal destek olması açısından yararlı olarak değerlendirilmektedir.

- Potansiyel zararlı uygulamalar: Toprağa oturtma enfeksiyon açısından, sıcak uygulamalar ise kanamayı artırma açısından potansiyel riskli uygulamalar olarak değerlendirilmektedir.

\section{SONUÇ VE ÖNERÍLER}

Lohusalık dönemi kadını destekleyen kültürel uygulamaların yanı sıra zararlı kültürel uygulamaları da kapsamaktadır. Lohusa izlemi yapacak hemşire ve ebelerin farklı toplumlarda değişen kültürel uygulamaları tanımaları ve sağlık hizmetini buna göre planlamaları hizmetin amacına ulaşması ve bakımın kalitesi açısından önemlidir.

Hazırlanan bu rehberin öğrenci ve mezun hemşire ve ebelere bir yol göstereceği ve bakımda standart oluşturacağı düşünülmektedir. Rehber veri toplama aracı olarak kullanıldığında eksikler görülüp tamamlanacak ve geliştirilecek niteliktedir. Lohusalık döneminde hangi kültürel özellikleri sorgulayacağını bilmeyen sağlık çalışanlarına ışık olacağı düşünülmektedir.

Dinç S. Şanlıurfa Merkezde Bulunan 4 Nolu Sağlık Ocağı'na Kayıtlı 0-1 Yaş Çocuğu Olan Annelerin Çocukların Bakımında Uyguladıkları Geleneksel Uygulamalar. HEMARGE Dergisi 2005; 1(2):53-63.

Ĕgri G, Konak A. Doğum Sonu Dönem ile İlgili Geleneksel İnanç ve Uygulamalara Dünya'dan Ve Türkiye'den Örnekler. Journal of World of Turks 2011;3 (1):143-54.

Geçkil E, Şahin T, Ege E. Traditional Postpartum Practices of Women and Infants and the Factors İnfluencing Such Practices in South Eastern Turkey. Midwifery $2009 ; 25(1): 62-71$.

Gökdolun M, Akdolun Balkaya N. 0-6 Yaş Bebeği Olan Annelerin Anne Sütünü Artırmaya Yönelik Geleneksel Uygulamaları. ADÜ Tıp Fakültesi Dergisi 2013; 14(1) : $31-41$.

Gölbaşı Z, Eğri G. Doğum sonu dönemde annenin bakımına yönelik yapılan geleneksel uygulamalar. Cumhuriyet Tip Dergisi 2010; 32(3): 276-82.

Grigoriadis S, Dennis C, Kenneth F, Gail R, Sarah R, Lori R, Cornelia C. Postpartum cultural practices: a systematic review of the evidence. Annals of General Psychiatry 2008;7 (1): 163.

Işık MT, Akçınar M, Kadıoğlu M. Mersin ilinde gebelik, doğum ve loğusalık dönemlerinde anneye ve yenidoğana yönelik geleneksel uygulamalar. UİBD 2010;7(1): 63-84.

Jarrah S, Bond E. Jordanian Women's Postpartum Beliefs: An Exploratory Study. İnternational Journal of Nursing Practice 2007;13(5):289-95. 
Kaewsarn P, Moyle W, Creedy D. Traditional Postpartum Practices Among Thai Women. Journal of Advanced Nursing 2003a; 41(4): 358-66

Kaewsarn P, Moyle W, Creedy D. Thai Nurses' Beliefs About Breastfeeding and Postpartum Practices. J Clin Nurs. 2003b;12(4):467-75.

Karaaslan M. Kaşkay Türklerinde Doğum Çevresinde Gelişen Inanç ve Pratikler. Turkish Studies - International Periodical for The Languages, Literature and History of Turkish or Turkic 2011; 6(3):1435-48.

Kim-Godwin YS. Postpartum Beliefs and Practices Among Non-Western Cultures. The American Journal of Maternal/Child Nursing 2003;28(2):74-8; 79-80.

Küçük A. Doğu Karadeniz Yöresi Doğum Sonrası İnaniş ve Uygulamalarında Cadı/Obur. Karadeniz (Black Sea- Çernoye More) Sosyal Bilimler Dergisi 2011;3(12):123-35.

Lafcı D,Erdem E. Traditional Practices Regarding Mother and Infant Care of 15-49 Year Old Married Women in The Postpartım Period. Gaziantep Medical Journal 2014;20(3):226-36.

Ozsoy SA, Katabi V. A Comparison of Traditional Practices Used in Pregnancy, Labour and the Postpartum Period Among Women in Turkey and Iran. Midwifery 2008; 24(3): 291-300.

Raven JH, Chen Q, Tolhurst RJ, Garner P. Traditional Beliefs and Practices in the Postpartum Period in Fujian Province, China:A Qualitative Study. BMC Pregnancy and Childbirth 2007;7(8):1-11. Tanrıverdi G, Ünüvar R, Yalçın M, Sürer M, Acar P, Akçay E, Hacıalioğlu A ve ark. Çanakkale'de Yaşayan Romanların Purnell'in Kültürel Yeterlilik Modeli ile Değerlendirilmesi. Anadolu Hemşirelik ve Sağlık Bilimleri Dergisi 2012;15(4):244-53.
Thi, LM. Traditional Postpartum Practices Among Vietnamese Mothers: A Study in Anthi District, Hungyen Province. Faculty of Graduate Studies, Mahidol University, Bangkok, 2004, p. 132.

Thi ML, Pasandarttorn W, Rauyajin O. Traditional postpartum practices among Vietnamese mothers in anti distric, HungYen province. Master's thesis.

Sein KK. Beliefs and practices surrounding postpartum period among Myanmar women. Midwifery 2013; 29(11), 1257-1263.

Sis Çelik A, Çapık A, Engin R. Erzurum'da Gebelik ve Doğum Sonu Dönemde Yapılan Geleneksel Uygulamaların Belirlenmesi. Anadolu Hemşirelik ve Sağlık Bilimleri Dergisi 2012; 15(4):262-7.

Sütlü Uğurlu Z, Dayılar H, Çoban V, Ada Z. Ödemişte Bulunan Annelerin Bebek Bakımında Uyguladıkları Geleneksel Yöntemlerin Incelenmesi. Gümüşhane Üniversitesi Sağlık Bilimleri Dergisi 2013;2(3):342-60.

Tosun Güleroğlu F, Başer M, Cerit E, Yüzer S. Postpartum Dönemde Yapılan Geleneksel İnanç ve Uygulamalar. Turkiye Klinikleri Journal of Gynecology and Obstetrics 2014;24(2): 84-9.

Wang X, Wang Y, Zanzhou S, Wang J, Wang J. A Population-Based Survey of Women's Traditional Postpartum Behaviours in Northern China. Midwifery 2008; 24(2): 238-45.

Yalçın H. Gebelik, Doğum, Lohusalık Ve Bebek Bakımına Ilişkin Geleneksel Uygulamalar (Karaman örneği). Çocuk Sağlığı ve Hastalıkları Dergisi 2012; 55(Ocak-Mart): 19-31.

Zamani A. Traditional Practices in Postnatal Care: The Malay Community in Malaysia. TSMJ 2001;9(2):0-31. 